\title{
Isolation and Properties of Cytoplasmic $\alpha$-Glycerol 3-Phosphate Dehydrogenase from the Pectoral Muscle of the Fruit Bat, Eidolon helvum
}

\author{
Femi Kayode Agboola ${ }^{\dagger, *}$, Alan Thomson* and Adeyinka Afolayan ${ }^{\dagger}$ \\ Department of Biochemistry, Obafemi Awolowo University, Ile-Ife, Nigeria \\ Division of Biological Sciences, Institute of Biological and Environmental Sciences, Lancaster University, Lancaster, LAI 4YQ, UK
}

Received 24 June 2002, Accepted 10 October 2002

\begin{abstract}
Cytoplasmic $\alpha$-glycerol-3-phosphate dehydrogenase from fruit-bat-breast muscle was purified by ion-exchange and affinity chromatography. The specific activity of the purified enzyme was approximately 120 units/mg of protein. The apparent molecular weight of the native enzyme, as determined by gel filtration on Sephadex G-100 was $\mathbf{5 9 , 5 0 0} \pm 650$ daltons; its subunit size was estimated to be $\mathbf{3 5 , 7 0 0} \pm 140$ by SDS-polyacrylamide gel electrophoresis. The true Michaelis-Menten constants for all substrates at pH 7.5 were $3.9 \pm 0.7 \mathrm{mM}, 0.65 \pm 0.05 \mathrm{mM}, 0.26 \pm 0.06 \mathrm{mM}$, and $0.005 \pm 0.0004 \mathrm{mM}$ for L-glycerol-3-phosphate, $\mathrm{NAD}^{+}$, DHAP, and NADH, respectively. The true Michaelis-Menten constants at $\mathrm{pH} \quad \mathbf{1 0 . 0}$ were $2.30 \pm 0.21 \mathrm{mM}$ and $0.20 \pm 0.01 \mathrm{mM}$ for L-glycerol-3-phosphate and $\mathrm{NAD}^{+}$, respectively. The turnover number, $k_{\text {cat }}$, of the forward reaction was $1.9 \pm 0.2 \times 10^{4} \mathrm{~s}^{-1}$. The treatment of the enzyme with 5,5'-dithiobis-2-nitrobenzoic acid (DTNB) under denaturing conditions indicated that there were a total of eight cysteine residues, while only two of these residues were reactive towards DTNB in the native enzyme. The overall results of the in vitro experiments suggest that $\alpha$-glycerol-3phosphate dehydrogenase of the fruit bat preferentially catalyses the reduction of dihydroxyacetone phosphate to glycerol-3-phosphate.
\end{abstract}

Keywords: Animal/bat flight, Fruit bat, Glycerol-3-phosphate dehydrogenase, Pectoral/breast muscle

*To whom correspondence should be addressed.

E-mail: fkagbo@oauife.edu.ng; fkagboola@yahoo.co.uk

Note: The material presented in this report is part of the work presented by F.K. Agboola in partial fulfillment for the degree of Doctor of Philosophy in Biochemistry at the Obafemi Awolowo University, Ile-Ife, Nigeria.

\section{Introduction}

There are two distinct forms of alpha-glycerophosphate dehydrogenase. There is a mitochondrial (particulate) flavinlinked glycerol-3-phosphate dehydrogenase (m- $\alpha-\mathrm{GDH}, \mathrm{EC}$ 1.1.1.99) and a cytoplasmic (soluble) $\mathrm{NAD}^{+}$-linked glycerol3-phosphate dehydrogenase (sn-glycerol-3-phosphate: NAD ${ }^{+}$ oxidoreductase, $\alpha-G D H$, EC 1.1.1.18) (Green, 1936; von Euler et al., 1937), which are capable of reducing dihydroxyacetone phosphate (DHAP) to L-glycerol-3phosphate $(\alpha-\mathrm{GP})$. The cytosolic $\alpha-\mathrm{GDH}$, as well as the mitochondrial $\alpha-G D H$, is of interest because it catalyses a reaction in the metabolic pathway that links glycolysis with lipid biosynthesis and breakdown. It is not surprising that the enzyme is reported to be present in many animal tissues and microorganisms.

The energy source for the long flight of bats, the only mammal capable of flight, is of particular interest from both an evolutionary and physiological viewpoints. The sustained flights of bats, such as in nocturnal foragings and migratory movement, may require energy that is derived from lipids from the fat deposit in the breast muscle in a similar way to that which occurs in insect muscles during flight (George and Jyoti, 1955; Bennakkers, 1969). Fruit bats probably satisfy their fat requirement through the endogenous conversion of carbohydrates, which form the majority of their diet (Okon et al., 1978). Fatty acid oxidation has long been recognized as the source of energy for migratory animals, such as insects (Gilbert, 1967; Bennakkers, 1969). Furthermore, the importance of $\alpha-\mathrm{GDH}$ in the flight muscle of insects that use carbohydrate as fuel, in relation to the energy need during flight, has also been extensively studied (Chance and Sacktor, 1958; Sacktor, 1965). In these insects, the enzyme appears to be kinetically suited to the function in the glycerophosphate shunt. There is no information, to the best of our knowledge, on $\alpha$-glycerol phosphate dehydrogenase from any bat tissue or organ. 
In this study, we purified $\alpha$-glycerol-3-phosphate dehydrogenase from the breast muscle of the fruit bat, Eidolon helvum, and evaluated some of its physical and catalytic characteristics. Our investigations suggest that the enzyme is kinetically favored towards the production of $\alpha$-glycerol phosphate. Presently, it is impossible to confirm that cytosolic $\alpha-\mathrm{GDH}$ of the fruit bat essentially catalyses the reduction of DHAP under physiological conditions. Further studies (such as the determination of the physiological $\mathrm{pH}$, level of the substrates, and other equilibrium parameters) will hopefully help to elucidate the proper role of $\alpha-\mathrm{GDH}$ in the bat muscle.

\section{Materials and Methods}

Materials DEAE-Sephacel, Reactive Blue 2-crosslinked agarose, dihydroxyacetone phosphate, DL- $\alpha$-glycerol phosphate, Dfructose-1,6-diphospate, alcohol dehydrogenase (from Baker's yeast), aldolase (from rabbit muscle), $\alpha$-nicotinamide adenine dinucleotide (oxidized and reduced forms), and creatine phosphate were purchased from the Sigma Chemical Company, St. Louis, USA. The other reagents that were obtained from Sigma Chemical Company are 5,5'-dithiobis-2-nitrobenzoic acid, adenosine-5'triphosphate, and the gel filtration marker proteins. Sephadex G-100 was purchased from Pharmacia AB, Stockholms, Sweden. All the other reagents that were used were of analytical grade and obtained from either Sigma or BDH. The bats were collected at the International Institute for Tropical Agriculture (IITA), Ibadan, Nigeria.

\section{Purification of cystolic $\alpha$-glycerol-3-phosphate dehydrogenase} from fruit-bat-breast muscle All the procedures were carried out at temperatures between $0-4^{\circ} \mathrm{C}$. All the buffers contained $1 \mathrm{mM}$ EDTA and $5 \mathrm{mM}$ 2-mercaptoethanol. The fruit bats were collected from farms and brought into the laboratory in cages. Typically, a fruit bat was rendered unconscious by a blow on the back of the head. The breast muscle was quickly excised, blotted with filter paper, weighed, and placed in ice. Approximately $1,500 \times g$ (wet weight) of tissue (collected from 25 bats) was used for this preparation. A $50 \%(\mathrm{w} / \mathrm{v})$ homogenate of the muscle was prepared in a $0.1 \mathrm{M}$ sodium phosphate buffer, $\mathrm{pH} 7.2$ (buffer A) using a Warring Blender. The homogenate was occasionally stirred for $1 \mathrm{~h}$, then centrifuged at $12,400 \times g$ for $30 \mathrm{~min}$ at $4^{\circ} \mathrm{C}$. The supernatant was filtered through a loose plug of glass wool and saved. The debris was resuspended and homogenized in one volume of the same buffer and recentrifuged at the same speed. The resulting supernatant solutions from the two homogenization steps were combined and the total volume was subjected to ammonium sulphate precipitation. The precipitate, obtained between a $40-70 \%$ $\left(\mathrm{NH}_{4}\right)_{2} \mathrm{SO}_{4}$ saturation, was collected after centrifugation at 30,000 $\times g$ for $30 \mathrm{~min}$ and resuspended in a small amount of $5 \mathrm{mM}$ Tris$\mathrm{HCl}, \mathrm{pH} 7.6$ (buffer B). The suspension was dialyzed against two changes of buffer B.

The dialysate that was obtained was subjected to heating at $50^{\circ} \mathrm{C}$ for 3-5 min and was cooled rapidly in an ice-bath. The heatinactivated precipitate was later removed by centrifugation at $30,000 \times g$. The supernatant was stirred into $200 \mathrm{ml}$ of Reactive Blue 2-crosslinked agarose that was previously washed with several volumes of distilled water and equilibrated in buffer B. The slurry was packed into a $5 \times 30 \mathrm{~cm}$ column and eluted with $800 \mathrm{ml}$ of $0.5 \mathrm{M} \mathrm{KCl}$ in buffer B. The eluate was brought to $60 \%\left(\mathrm{NH}_{4}\right)_{2} \mathrm{SO}_{4}$ saturation by the addition of a saturated-ammonium-sulphate solution (761.4 g/litre) in buffer B. The precipitate that formed after $10 \mathrm{~h}$ was collected at $30,000 \times g$ for $30 \mathrm{~min}$, and was suspended in a minimal amount of the same buffer. The suspension was dialyzed for $12 \mathrm{~h}$, with four changes against buffer $\mathrm{B}$.

The dialysate, after clarification by centrifugation, was applied onto a DEAE-Sephacel column $(2.5 \times 40 \mathrm{~cm})$. The column was first washed with $250 \mathrm{ml}$ of buffer $\mathrm{B}$, followed by elution with linear gradient $(0-0.3 \mathrm{M} \mathrm{KCl})$ of $400 \mathrm{ml}$ in buffer $\mathrm{B}$. The flow rate of the column was $30 \mathrm{ml} / \mathrm{h}$. The active fractions ( $4 \mathrm{ml}$ each) were pooled and concentrated by ultrafiltration in an Amicon PM 10 membrane at $30 \mathrm{psi}$. The concentrated sample was equilibrated by dialysis with $0.04 \mathrm{M}$ sodium phosphate, $\mathrm{pH} 6.6$ (buffer $\mathrm{C}$ ), and rechromatographed on a DEAE-Sephacel column $(2.5 \times 40 \mathrm{~cm})$ that was previously equilibrated in the same buffer. The column was eluted with buffer $\mathrm{C}$ at a flow rate of $30 \mathrm{ml} / \mathrm{h}$ until the absorbance at $280 \mathrm{~nm}$ of the eluate (in $4 \mathrm{ml}$ fractions) was less than 0.05 . The enzyme was not bound, and the active flow-through fractions were pooled and concentrated by ultrafiltration on the PM 30 membrane.

The partially-purified enzyme was further purified by affinity chromatography on a Procion Red P-Sepharose 4B column $(1 \times$ $2.5 \mathrm{~cm}$ ) that was prepared by Balmforth (1982), then preequilibrated with buffer B. The column was first washed with 100 $\mathrm{ml}$ of buffer B before the elution of $\alpha-\mathrm{GDH}$ with a $200 \mathrm{ml}$ linear gradient of $0-0.1 \mathrm{M}$ DL- $\alpha$-glycerol-3-phosphate, according to McGinnis and Vellis (1974). The flow rate was kept at $60 \mathrm{ml} / \mathrm{hr}$, and fractions of $4 \mathrm{ml}$ were collected. The active fractions were pooled. The pool was first dialyzed against buffer $\mathrm{C}$ in order to remove DL- $\alpha$-GP, then concentrated by dialysis in $50 \%$ glycerol in the same buffer. The final purification step on the Sephadex G-100 column $(2.5 \times 100 \mathrm{~cm})$ was according to White and Kaplan (1969). The active fractions were pooled and dialyzed against $50 \%$ glycerol in $0.1 \mathrm{M}$ sodium phosphate, $\mathrm{pH}$ 7.2.

Protein assay The protein concentration was measured during the purification procedures by the method of Warburg and Christian (1942). The protein concentration of the pure enzyme was determined by the method of Lowry et al. (1951) using bovine serum albumin as the standard.

Enzyme assay The $\alpha$-GDH activity was measured spectrophotometrically at $25^{\circ} \mathrm{C}$ by following the disappearance of $\mathrm{NADH}$ that accompanies the reduction of DHAP (forward assay), or the oxidation of $\alpha$-GP and formation of NADH (reverse assay), respectively, at $340 \mathrm{~nm}$ (Marquart and Brosemer, 1966; Lee and Craine, 1971; Gonzalez-Cerezo and Daziel, 1982). The fructose1,6-bisphosphate (FBP)-linked assay of Marquart and Brosemer (1966) was used with a slight modification for the determination of activity during the purification procedures. The FBP-linked assay gave the same reaction rate as the forward assay, while the reverse assay was much slower. A typical assay mixture contained, in the final concentration, $50 \mathrm{mM}$ Tris $\mathrm{HCl}$, $\mathrm{pH} 7.5$ (containing $1 \mathrm{mM}$ EDTA and $2 \mathrm{mM}$ 2-mercaptoethanol), $0.5 \mathrm{mM}$ DHAP and $0.1 \mathrm{mM}$ NADH for the forward reaction, and $80 \mathrm{mM}$ glycine- $\mathrm{NaOH}, \mathrm{pH}$ 10.0 (containing $0.5 \mathrm{mM}$ EDTA), $0.3 \mathrm{mM}$ 2-mercaptoethanol, 
$0.5 \mathrm{mM} \mathrm{NAD}^{+}$for the reverse reaction. The assay mixture may contain up to $20 \mathrm{mM}$ hydrazine (Marquart and Brosemer, 1966; Lee and Craine, 1971; McGinnis and Vellis, 1974; GonzalezCerezo and Daziel, 1982). The FBP-linked assay contained $75 \mathrm{mM}$ Tris-HCl, pH 7.5 (containing $0.5 \mathrm{mM}$ EDTA, $5 \mathrm{mM} \quad$ 2mercaptoethanol, $0.14 \mathrm{mM}$ NADH, $5 \mathrm{mM}$ FBP, $20 \mathrm{mg}$ of rabbitmuscle-triosephosphate isomerase, and $20 \mu \mathrm{g}$ of rabbit-musclefructosebisphosphate aldolase.) In all cases, the unit of enzyme activity was defined as the amount of enzyme that catalyses the disappearance or formation of $1.0 \mu \mathrm{mol}$ of NADH per min.

Polyacrylamide gel electrophoresis Polyacrylamide gel electrophoresis in the absence of SDS was performed on $7.5 \%$ gels on either the rod or slab apparatus in the Tris-glycine buffer solution, $\mathrm{pH}$ 8.9. The slab gel electrophoresis was performed according to LKB manuals for a 2050 Midget Electrophoresis unit, while the rod gel electrophoresis was according to the Pharmacia manual. The proteins were stained with Coomassie Brilliant Blue $\mathrm{R}$, while the gels were stained for enzyme activity according to the methods of Fondy et al. (1971), and McGinnis and Vellis (1974).

SDS-PAGE was performed on the $10 \%$ rod or slab gel using the Tris-glycine or phosphate buffer system of Weber and Osborn (1975). The apparatus were as mentioned previously. The $M_{r}$ standards that were used were obtained from Sigma (SDS-Dalton Mark VII-L kit, MW range 14,000-70,000).

Molecular weight determination The molecular weight of the native enzyme was estimated by gel filtration on a Sephadex G-100 column $(2.5 \times 85 \mathrm{~cm})$. The column was equilibrated and eluted with $0.1 \mathrm{M}$ sodium phosphate buffer, $\mathrm{pH} 7.2$, at a flow rate of 14 $\mathrm{ml} / \mathrm{h}$. The void volume was determined with bovine thyroglobulin (M 669,000). The standard proteins that were used in calibrating the column were baker's yeast alcohol dehydrogenase (M 141,000), bovine serum albumin (M 66,000), egg albumin (M 43,000), bovine erythrocyte carbonic anhydrase (M 29,000), bovine pancreas chymotrypsinogen A (M 25,000), and horse-heart myoglobin (M, 17,000).

Amino acid analysis The amino acid composition of the purified enzyme was determined by an automatic LKB-alpha amino acid analyzer after a $24-\mathrm{h}$ hydrolysis in $6 \mathrm{~N} \mathrm{HCl}$ at $110^{\circ} \mathrm{C}$ at the University of Edinburgh, Scotland, through the kind assistance of Mr. Akindele Famurewa.

Kinetic studies The kinetic parameters were evaluated from the secondary plots according to the method of Florini and Vestling (1951). The determination of the kinetic parameters for the forward reaction that involved the reduction of dihydroxyacetone phosphate (and oxidation of $\mathrm{NADH}$ ) was only performed at $\mathrm{pH}$ 7.5. The effect of glycerol-3-phosphate and $\mathrm{NAD}^{+}$concentrations on the velocity of the reaction in the reverse direction were measured at both $\mathrm{pH}$ 7.5 (in a $50 \mathrm{mM}$ Tris- $\mathrm{HCl}$ buffer) and $\mathrm{pH} 10.0$ (in a $80 \mathrm{mM}$ glycine$\mathrm{NaOH}$ buffer).

The effects of the added glycerol-3-phosphate on the rate of the forward reaction were studied at $\mathrm{pH} 7.5$ by varying the concentration of glycerol-3-phosphate at two fixed but different concentrations of the DHAP, according to the method of Dixon (1953) as modified by Lee and Craine (1971).
Effect of creatine phosphate and ATP The sensitivity of the $\alpha$ GDH activity to these metabolites was investigated, because of the possible roles of the compounds in the regulation of this enzyme (Guppy and Hochachka, 1974 a,b). The inhibitory effect of the creatine phosphate (CP) and ATP was studied at $\mathrm{pH} 7.5$ at various concentrations of creatine phosphate between 5 and $20 \mathrm{mM}$ while that of ATP ranged from 0.4 to $8.0 \mathrm{mM}$.

Reaction with 5,5'-dithiobis-2-nitrobenzoic acid (DTNB) The reaction of bat $\alpha-G D H$ with DTNB was carried out according to the method of Afolayan (1989). The modification was performed in a reaction mixture that contained $1.79 \mu \mathrm{M}$ enzyme and $0.5 \mathrm{mM}$ DTNB in a $0.05 \mathrm{M}$ sodium phosphate buffer, $\mathrm{pH} 8.0$ in the dark. The process was monitored by reading the absorbance at $412 \mathrm{~nm}$ and assaying for residual activity using the FBP-linked assay method. The number of reactive sulphydryl groups was calculated using the extinction coefficient of $1.36 \times 10^{4} \mathrm{M}^{-1} \mathrm{~cm}^{-1}$ and 1.39 $\times 10^{4} \mathrm{M}^{-1} \mathrm{~cm}^{-1}$ in the presence or absence of $6 \mathrm{M}$ guanidinium hydrochloride $(\mathrm{Gdn}-\mathrm{HCl})$ for the thionitrobenzoate (TNB) ion. The total number of the available sulphydryl $(\mathrm{SH})$ groups was determined by carrying out the reaction in the presence of $0.2 \%$ SDS or 6.4 M Gdn-HCl.

\section{Results}

Enzyme purification The results of the purification procedure are summarized in Table 1. The 40-70\% $\left(\mathrm{NH}_{4}\right)_{2} \mathrm{SO}_{4}$ precipitate contained more than $70 \%$ of the active enzyme in the crude homogenate. The procedure yielded a homogeneous $\alpha-\mathrm{GDH}$ with a specific activity of about $120 \mathrm{units} / \mathrm{mg}$ of protein, representing an increase in purification of about 850fold. All of the experiments that were presented in this report were carried out with this enzyme preparation. The enzyme was considered pure by the presence of a single band of protein after a polyacrylamide gel electrophoresis both in the presence and absence of SDS (figures not shown). Only one band each was obtained when the pure enzyme and crude extract were stained for $\alpha-G D H$ activity after the polyacrylamide gel electrophoresis under non-denaturing conditions (figures not shown).

Molecular weight determination The molecular weight of the native enzyme was estimated to be $59,500 \pm 650 \mathrm{Da}$ by gel filtration on Sephadex G-100. The subunit molecular weight estimated by SDS-PAGE was $35,700 \pm 140 \mathrm{Da}$. This suggests that the fruit bat $\alpha-G D H$ is a dimer. The minimum subunit molecular weight that was estimated from the amino acid composition was $30,047 \mathrm{Da}$, which corresponds to a molecular weight of about 60,000 Da for the dimeric enzyme.

Kinetic studies Figure 1 shows the typical LineweaverBurk plot of the initial reaction velocity against the DHAP concentrations at fixed NADH concentrations at $\mathrm{pH} 7.5$, as well the secondary slope and intercept plots. Table 2 presents a summary of the $K_{m}$ and the $V_{\max }$ values, estimated from the secondary plots. Figure 2 shows the Dixon plot of the product 
Table 1. Purification of fruit bat pectoral muscle $\alpha$-glycerol-3-phosphate dehydrogenase

\begin{tabular}{|c|c|c|c|c|c|}
\hline Step/Fraction & $\begin{array}{l}\text { Volume } \\
(\mathrm{ml})\end{array}$ & $\begin{array}{l}\text { Total } \\
\text { units }\end{array}$ & $\begin{array}{l}\text { Total } \\
\text { protein } \\
(\mathrm{mg})\end{array}$ & $\begin{array}{c}\text { Specific } \\
\text { activity } \\
\text { (units /mg) }\end{array}$ & $\begin{array}{l}\text { Purification } \\
\quad \text { fold }\end{array}$ \\
\hline Crude extract & 3,600 & 11,600 & 85,300 & 0.14 & 1.00 \\
\hline $40-70 \%$ ammonium sulphate precipitate & 520 & 8,860 & 32,700 & 0.27 & 1.90 \\
\hline Heat treatment & 505 & 7,750 & 11,800 & 0.66 & 4.71 \\
\hline Reactive Blue-Agarose batch elution & 800 & 7,690 & 3,380 & 2.28 & 16.30 \\
\hline $\begin{array}{l}\text { DEAE-Sephacel ion-exchange followed by ultrafiltration } \\
\text { on PM } 10 \text { membrane }\end{array}$ & 95 & 6,900 & 977 & 6.92 & 49.40 \\
\hline $\begin{array}{l}\text { Rechromatography on DEAE-Sephacel followed by } \\
\text { ultrafiltration on PM } 30 \text { membrane }\end{array}$ & 30 & 5,990 & 482 & 12.40 & 88.80 \\
\hline Procion red P-4B coupled to Sepharose $4 \mathrm{~B}$ & 45 & 3,510 & 79.2 & 44.30 & 316 \\
\hline $\begin{array}{l}\text { Gel filtration on Sephadex G-100 followed by } \\
\text { concentration by dialysis in } 50 \% \text { glycerol }\end{array}$ & 75 & 1,450 & 12.3 & 119 & 848 \\
\hline
\end{tabular}

Each step was carried out as described in the text. Activity was measured by using the fructose-1,6-bisphosphate-linked assay that involved aldolase and triosephosphate isomerase. Protein was determined by the method of Warburg and Christian [13]. One unit of activity is the amount that will catalyzed the oxidation of $1.0 \mu$ mole of NADH/min. Other workers [12, 30] had defined one unit of their preparation as the amount of enzyme required to catalyze a 1.00 optical density change per min and this is equivalent to $0.48 \mu$ mole $\mathrm{NADH} / \mathrm{min}$.
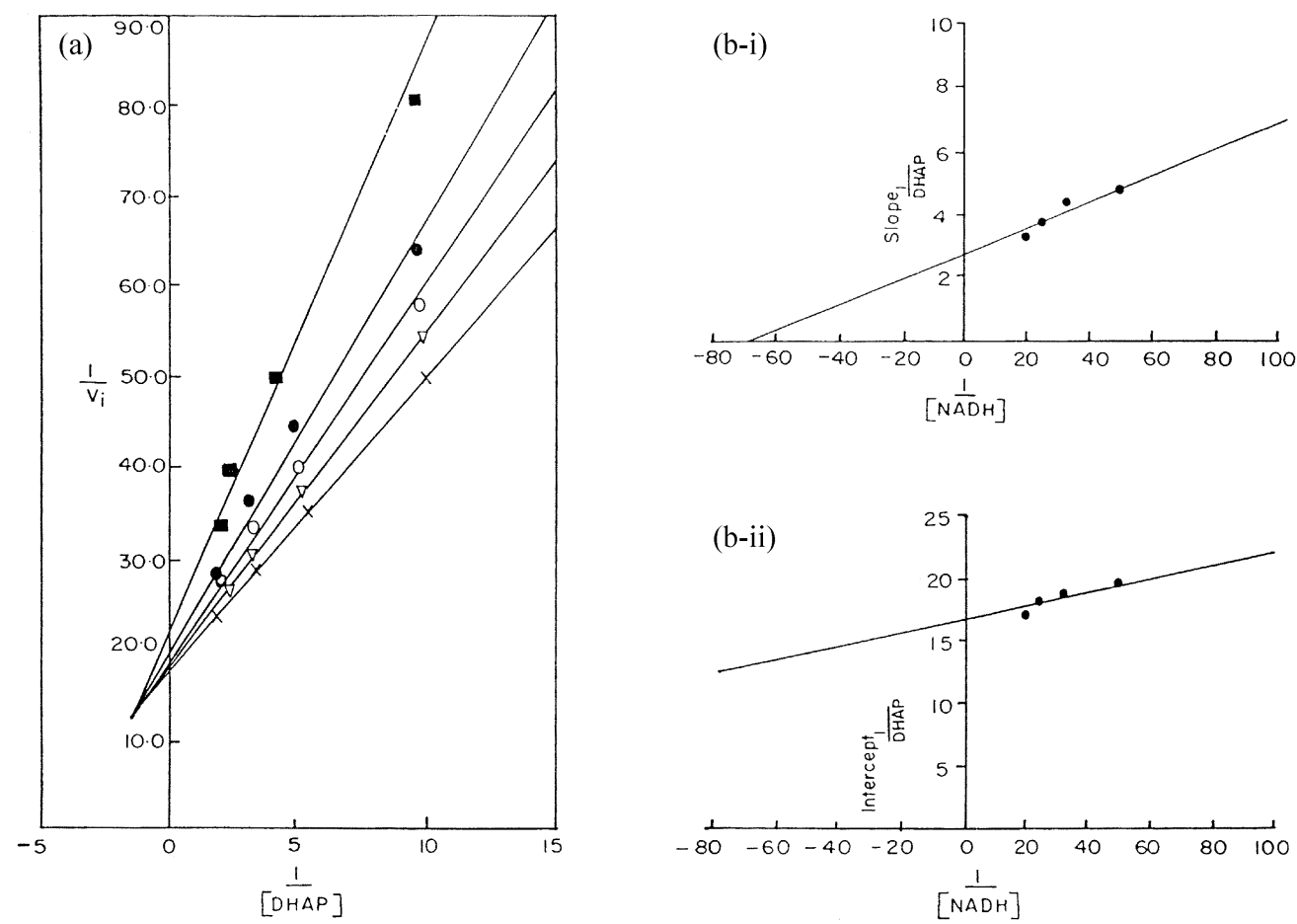

Fig. 1. Effect of DHAP concentration on the activity of fruit bat pectoral muscle $\alpha$-glycerophosphate dehydrogenase. (a) The LineweaverBurk plot showing the effect of varying the concentraion of DHAP at different fixed NADH concentrations. The reaction mixture of $1 \mathrm{ml}$ contained $50 \mathrm{mM}$ Tris- $\mathrm{HCl}, \mathrm{pH} 7.5,10 \mu \mathrm{l}$ of the enzyme $(0.015 \mathrm{mg} / \mathrm{ml})$, different DHAP concentrations (varied between 0.1 and $0.5 \mathrm{mM}$ ), and indicated amount of NADH: viz $0.01 \mathrm{mM}(\boldsymbol{\square}), 0.02 \mathrm{mM}(\boldsymbol{\bigcirc}), 0.03 \mathrm{mM}(\bigcirc), 0.04 \mathrm{mM}(\nabla)$, and $0.05 \mathrm{mM}(\times)$. The initial velocity, $\mathrm{V}_{\mathrm{i}}$, of the reaction was recorded as change decrease in absorbance at $340 \mathrm{~nm}$ per min. (b) Secondary plots of data from the LineweaverBurk plots showing the effect of varying NADH concentrations. (i) slope ${ }_{1 / D H A P}$ replot (ii) $1 / \mathrm{v}_{\mathrm{i}}$-axis intercept replot.

inhibition of the forward reaction (DHAP $+\mathrm{NADH} \rightarrow \mathrm{G} 3 \mathrm{P}+$ $\mathrm{NAD}^{+}$) by added glycerol-3-phosphate. The inhibition constant, $K_{i}$, for glycerol-3-phosphate was estimated to be
$9.4 \pm 2.9 \mathrm{mM}$. The nature of the inhibition is non-competitive with respect to DHAP. 
Table 2. Kinetic parameters of fruit bat pectoral muscle $\alpha$-glycerophosphate dehydrogenase

\begin{tabular}{|c|c|c|c|c|c|c|c|c|}
\hline \multirow{2}{*}{ Parameter } & \multicolumn{8}{|c|}{ Substrate } \\
\hline & DHAP & NADH & & GP & & & $\mathrm{NAD}^{+}$ & \\
\hline $\mathrm{pH}$ & $7.5^{\mathrm{a}, \mathrm{b}}$ & $7.5^{\mathrm{a}, \mathrm{d}}$ & $7.5^{\mathrm{a}, \mathrm{e}}$ & $10^{\mathrm{b}, \mathrm{e}}$ & $10^{\mathrm{ce} e}$ & $7.5^{\mathrm{a}, \mathrm{d}}$ & $10^{\mathrm{b}, \mathrm{e}}$ & $10^{\mathrm{ce} e}$ \\
\hline$K_{m}(\mathrm{mM})$ & $0.26 \pm 0.05$ & $0.005 \pm 0.0004$ & $3.9 \pm 0.67$ & $2.3 \pm 0.21$ & $2.6 \pm 0.06$ & $0.65 \pm 0.06$ & $0.20 \pm 0.01$ & $0.35 \pm 0.05$ \\
\hline$V_{\max }($ units/ml $)$ & $20 \pm 2.2$ & $20 \pm 2.2$ & $1.1 \pm 0.27$ & $1.7 \pm 0.36$ & $1.9 \pm 0.37$ & $1.1 \pm 0.27$ & $1.7 \pm 0.36$ & $1.9 \pm 0.37$ \\
\hline$V_{\max }(\mu \mathrm{M} / \mathrm{s})$ & $330 \pm 36$ & $330 \pm 36$ & $18 \pm 4.5$ & $28 \pm 5.9$ & $31 \pm 6.1$ & $18 \pm 4.5$ & $28 \pm 5.9$ & $31 \pm 5.9$ \\
\hline$k_{\text {cat }}\left(\mathrm{s}^{-1}\right)$ & $19000 \pm 2000$ & $19000 \pm 2000$ & $51 \pm 13$ & $78 \pm 17$ & $86 \pm 17$ & $51 \pm 13$ & $78 \pm 17$ & $86 \pm 16$ \\
\hline$k_{c a l} / K_{m} \times 10^{-5}\left(\mathrm{M}^{-1} \mathrm{~s}^{-1}\right)$ & $870 \pm 190$ & $3300 \pm 2700$ & $0.14 \pm 0.02$ & $0.35 \pm 0.03$ & $0.38 \pm 0.08$ & $0.80 \pm 0.07$ & $4.1 \pm 0.03$ & $2.3 \pm 0.68$ \\
\hline
\end{tabular}

All $K_{m}$ and $V_{\max }$ values are means of five determinations. Assays were carried out in the following buffers: $50 \mathrm{mM}$ Tris- $\mathrm{HCl}$ containing $1 \mathrm{mM}$ EDTA and $1 \mathrm{mM}$ 2-mercaptoethanol (a), $80 \mathrm{mM}$ glycine- $\mathrm{NaOH}$ containing $0.8 \mathrm{mM}$ EDTA and $0.3 \mathrm{mM}$ 2-mercaptoethanol (b), and $80 \mathrm{mM}$ glycine- $\mathrm{NaOH}$ containing $0.8 \mathrm{mM}$ EDTA and $20 \mathrm{mM}$ hydrazine sulphate (c). Values are for the forward reaction (d) and backward reaction (e). These kinetic parameters were evaluated from the secondary plots according to the method of Florini and Vestling (1951) following an ordered $\mathrm{Bi}$ Bi systesm for NAD+dependent dehydrogenase. One unit of activity is as defined in the text. The maximum velocity in $\mathrm{mM} / \mathrm{s}$ is expressed as micromolar NADH concentration that appeared or disappeared per second. The $k_{c a t}$ (catalytic efficiency) was estimated from the expression, $V_{\max }=\mathrm{E}_{\mathrm{T}} k_{c a l}$, where $\mathrm{E}_{\mathrm{T}}$ is the enzyme concentration in the assay mixture. $k_{c a l} / K_{m}$ is known as the specificity constant.

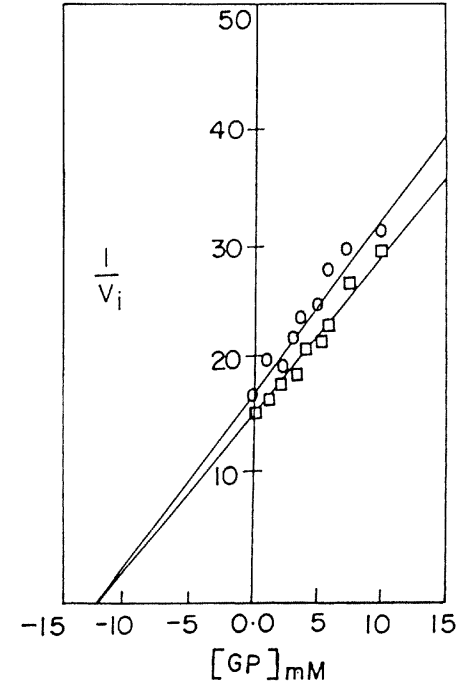

Fig. 2. Dixon plot of the inhibition of the forward reaction by glycerol-3-phosphate. The concentration of the inhibitor, $\alpha$-GP was varied between 1 and $10 \mathrm{mM}$ while the concentrations of DHAP were fixed at $0.4 \mathrm{mM}(\bigcirc)$ and $0.6 \mathrm{mM}(\square)$, respectively. For the details of the assay, see the text.

Effects of creatine phosphate and ATP Creatine phosphate caused no significant inhibition of the fruit-bat-muscle $\alpha-\mathrm{GDH}$, with an inhibition that was less than $10 \%$ at $16 \mathrm{mM}$ (Fig. 3). The enzyme was inhibited by ATP with a $35 \%$ inhibition at $3 \mathrm{mM}$ ATP and almost $50 \%$ around $8 \mathrm{mM}$ (Fig. 3).

Reaction with DTNB DTNB rapidly inactivated the enzyme at $\mathrm{pH}$ 8.0. This inactivation process increased with increasing concentrations of the reagent. After one hour, less than $20 \%$ of the activity remained in all of the reagent concentrations that were tested. The enzyme treatment with $0.5 \mathrm{mM}$ DTNB at $\mathrm{pH} 8$ released an average of 1.68 mole of

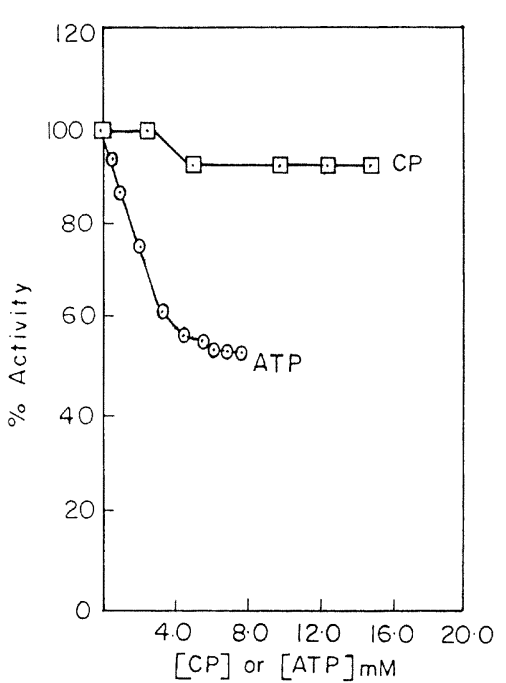

Fig 3. Effect of ATP and creatine phosphate on fruit bat pectoral muscle $\alpha$-glycerophosphate dehydrogenase. Assays were carried out in $50 \mathrm{mM}$ Tris- $\mathrm{HCl}, \mathrm{pH} 7.5$, and $0.5 \mathrm{mM} \mathrm{NADH}$. The concentration of ATP was varied between 0.4 and $8.0 \mathrm{mM}$ while that of creatine phosphate was between 5 and $20 \mathrm{mM}$.

TNB per mol of enzyme after one hour with consequent loss (over $93.4 \%$ ) of the enzyme activity. The loss of activity followed a pseudo first-order kinetics with two phases (Fig. 4). The analysis showed an average of $0.82 \mathrm{SH}$ groups that were modified per mole of the enzyme in the initial fast phase with a half-life of $4.48 \mathrm{~min}$ and a rate constant of $2.55 \times 10^{-1}$ $\mathrm{min}^{-1}$. In the slow phase, $0.8 \mathrm{SH}$ was modified with a half-life of $37.96 \mathrm{~min}$ and a rate constant of $1.83 \times 10^{-2} \mathrm{~min}^{-1}$. When the enzyme was treated with $0.5 \mathrm{mM}$ DTNB in the presence of SDS, about 8 moles of SH groups per mol of enzyme were modified. This represents the total number of sulphydryl groups in enzyme. 


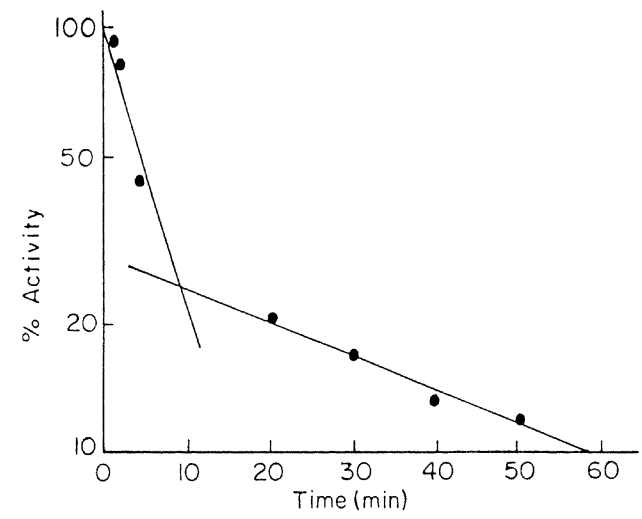

Fig. 4. Semilog plot of the rate of inactivation (loss of activity) during modification with DTNB. The enzyme solution $(1.79 \mathrm{mM})$ was incubated with $0.5 \mathrm{mM}$ DTNB in $0.05 \mathrm{mM}$ sodium phosphate buffer, $\mathrm{pH} 8.0$, in the dark at $25^{\circ} \mathrm{C}$. Aliquots were removed at indicated times and assayed for the residual activity by the standard FDP linked method.

Amino acid composition Table 3 shows the amino acid composition of the enzyme. Cysteine and trytophan could not be quantitatively estimated after acid hydrolysis. Since the analysis was only obtained from a 24-h hydrolyzate, then the amino acids contents that were determined may be slightly underestimated.

\section{Discussion}

Cytoplasmic $\alpha$-glycerol-3-phosphate dehydrogenase from the pectoral (breast) muscle of the fruit bat, Eidolon helvum Kerr, was purified to homogeneity using a procedure that involved ion-exchange chromatography (DEAE-Sephacel) and affinity chromatographies on Reactive Blue 2-Agarose and Procion Red P-Sepharose 4B. The purified enzyme was stored in 50\% glycerol or sucrose, since it was inactivated when stored in ammonium sulphate (Sellinger and Miller, 1959; Fondy et al., 1968). Although affinity chromatography was previously used for the purification of $\alpha-\mathrm{GDH}$ by other workers (Kornbluth $e t$ al., 1974; McGinnis and Vellis, 1974; Ostro and Fondy, 1977; Koekmoer et al., 1995), the use of triazine dye as a ligand is novel. The affinity of various reactive chlorotriazinyl dyes for a wide range of proteins, and its application in enzyme purification and as site-specific inhibitors, has been discussed (Turner, 1981). The specific activity of $\alpha-$ GDH (120 units per mg of protein, $\mathrm{pH}$ 7.5) is, however, slightly lower than the ones that were obtained for the same enzyme from honeybeeflight and rabbit muscles (Marquart and Brosemer, 1966; Fondy et al., 1971)

The molecular weight of the purified enzyme is estimated to be about 60,000 with a subunit size of 36,000 . The enzyme is, therefore, a dimer like the $\alpha$-GDHs from honeybee (Brosemer and Marquart, 1966; Marquart and Brosemer, 1966), rat tissues (Fondy et al., 1968; 1971), rabbit muscle
Table 3. Amino acid composition of fruit bat pectoral muscle $\alpha-$ glycerophosphate dehydrogenase

\begin{tabular}{cc}
\hline Amino acid & $\begin{array}{c}\text { Number of } \\
\text { residue }\end{array}$ \\
\hline Asp/Asn & 24 \\
Glu/Gln & 11 \\
Ser & 13 \\
His & 12 \\
Gly & 16 \\
Thr & 16 \\
Arg & 10 \\
Ala & 41 \\
Try & 3 \\
Met & 11 \\
Val & 17 \\
Phe & 17 \\
Ile & 22 \\
Leu & 30 \\
Lys & 31 \\
Trp & n.d \\
Pro & 16 \\
Cys & 8 \\
Total residue & 278 \\
Total residue molecular weight & 30,909 \\
Molecular weight of dimmer & 30,927 \\
\hline
\end{tabular}

The values for fruit bat $\alpha$-GDH were obtained from the $24 \mathrm{~h}$ hydrolyzate analysed by the LKB-alpha amino acid analyser. (a) Total weight of primary sequential unit represents the calculated molecular weight plus 18 due to the water associated with the terminal amino acid. (b) the total cysteine residue was determined by reaction with DTNB.

(Fondy et al., 1969), and chicken tissues (White and Kaplan, 1969), whose molecular weights range from 60,000 to 67,000 .

The inactivation of the fruit-bat-muscle $\alpha-$ GDH by DTNB indicates that the two cysteine residues are freely reactive towards DTNB, out of the total number of eight that are present in the enzyme. The remaining cysteine residues are probably buried in the interior of the enzyme molecule. The biphasic nature of the inactivation process suggests an asymmetrical association of the subunits in which each subunit cysteine residue reacted differently with the inactivating reagent (Degani and Degani, 1979).

The results of the kinetic experiments indicate that the enzyme preferably catalyses the reaction that involves the reduction of DHAP and oxidation of NADH in vitro, because of the low $K_{m}$ and high specificity constant $\left(k_{c a} / K_{m}\right)$ values for both DHAP and NADH (Table 2). These kinetic parameters are comparable with data that was obtained for $\alpha-G D H$ from chicken skeletal muscle (White and Kaplan, 1969). It can, therefore, be suggested that the enzymes from the breast muscle of both the fruit bat and chicken will probably perform 
similar functions. It has been suggested that chicken-breastmuscle $\alpha-\mathrm{GDH}$ is involved in the regeneration of $\mathrm{NAD}^{+}$for maintaining maximum glycolytic activity for the anaerobic work (White and Kaplan, 1969). Generally, the formation of $\alpha$-glycerol-3-phosphate and NADH oxidation would lead to either the generation of $\alpha$-GP for phospholipid and triglyceride syntheses, the maintenance of the cytosolic NAD ${ }^{+}$ level during anaerobic glycolysis, or the production of reducing equivalents in the form of $\alpha$-GP for transport across the mitochondrial membrane, as elucidated in the glycerophosphate cycle (Ostro and Fondy, 1977). Alternatively, under aerobic conditions, as in insect flight muscles (with an abundant supply of tracheoles and denselypacked mitochondria) (Bennakker, 1969) and the oxygendependent squid mantle muscle (Guppy and Hochachka, 1978a), which possess significant carbohydrate-based aerobic potential, the $\alpha-G D H$ role is the reoxidation of NADH during carbohydrate degradation. Warkentin and Fondy (1973) suggested that $\alpha-\mathrm{GDH}$ in rabbit liver is involved in the conversion of glycerol-3-phosphate to DHAP from glycerol during gluconeogenesis. It should be noted that $\alpha-G D H$ catalyses near equilibrium reaction in the cell; therefore, it is not considered a regulatory enzyme. The path of carbon flow from mainline glycolysis will depend on the level of NADH, $\alpha$-GP, and creatine phosphate (Guppy and Hochachka, 1978a).

The results of the product inhibition experiment showed that glycerol-3-phosphate was a non-competitive inhibitor of the reduction of DHAP (Fig. 2). The sensitivity of $\alpha-G D H$ to feedback inhibition by $\alpha$-GP determines its role(s) in the tissue of origin. Fruit bat $\alpha-\mathrm{GDH}$ sensitivity to product inhibition by $\alpha$-GP is low, because of its high $K_{i}$ value. In almost all of the tissues that were studied, glycerol-3phosphate is not only one of the substrates, but also one of the modifiers of the NAD-linked glycerol-3-phosphate dehydrogenase (Lee and Craine, 1971; Guppy and Hochachka, 1978 a,b; Brosemer and Marquart, 1966; Kito and Pizer, 1969).

Creatine phosphate levels did not significantly affect the activity of fruit bat $\alpha-\mathrm{GDH}$ (Fig. 3). It is possible that the inhibitory effect that was observed at high concentrations of creatine phosphate may be the result of the high ionic strength that was introduced by the addition of this reagent (Sellinger and Miller, 1959). Creatine phosphate has been suggested as an alternative source of energy, at least for the initiation of flight in this bat (Afolayan and Daini, 1986). ATP inhibited the enzyme only about $35 \%$ at $3 \mathrm{mM}$. This probably means that if the ATP levels do not drop below $3 \mathrm{mM}$, then ATP may not be an important regulator of this enzyme. ATP has been reported to be a competitive inhibitor with respect to NADH of dehydrogenases (Holbrook et al., 1975).

Acknowledgments This research work was supported by grants (numbers 1425FE and 1425RE) from the University Research Committee (URC) of the Obafemi Awolowo
University, Ile-Ife, Nigeria that was awarded to A.A. FKA would like to acknowledge with thanks the fellowship that was granted by the National Universities Commission of Nigeria under the World Bank Programme. The permission of the University of Lancaster, UK and the Division of Biological Sciences of the same University to allow FKA to utilize the fellowship in the institution is also gratefully acknowledged. We thank the International Institute for Tropical Agriculture (IITA), Ibadan, Nigeria, for allowing us to collect bats within its premises.

\section{References}

Afolayan, A. (1989) The essential cysteine of Candida utilis glucose-6-phosphate dehydrogenase. Nig. J. Natl. Sci. 4, 61-65.

Balmfort, A. J. (1982) Production, purification and characterization of glyoxylate dehydrogenase from Sclerotium rolfsii (Sacc). $\mathrm{Ph} . \mathrm{D}$. Thesis, Lancaster University, Lancaster, U.K; 1982.

Bennakkers, A. M. T. (1969) Carbohydrates and fat as a fuel for insect flight: A comparative study. J. Insect Physiol. 15, 353361.

Brosemer, R. W. and Marquart, R. R. (1966) Insect extramitochondrial glycerophosphate dehydrogenase: II. Enzymic properties and amino acid composition of the enzyme from honey bee (Appis mellifera) Thoraces. Biochem. Biophys. Acta 128, 464-473.

Chance, B. and Sacktor, B. (1958) Respiratory metabolism of insect flight muscle: II Kinetic of respiratory enzymes in flight muscle sarcosomes. Archs. Biochem. Biophys. 76, 509-531.

Degani, Y. and Degani, C. (1979) Subunit selective chemical modifications of creatine kinase. Evidence for asymmetrical associations of the subunits. Biochem. 15, 5917-5923.

Dixon, M. (1953) The determination of enzyme inhibitor constants. Biochem. J. 55, 170-171.

Florini, J. R. and Vestling, C. S. (1951) Graphical determination of the dissociation constants from two substrate enzyme system. Biochem. Biophys. Acta 25, 575-578.

Fondy, T. P., Herwig, K. J., Sollohub, S. J. and Rutherford, D. B. (1971) Isolation and structural properties of cytoplasmic glycerol-3-phosphate dehydrogenase from rat liver. Archs. Biochem. Biophys. 145, 583-590.

Fondy, T. P., Levin, L., Sollohub, S. J. and Ross, C. R. (1968) Structural studies on nicotinamide adenine dinucleotide linked L- $\alpha$-glycerol-3-phosphate dehydrogenase crystallized from rat skeletal muscle. J. Biol Chem. 243, 3148-3160.

Fondy, T. P., Ross, C. R. and Sollohub, S. J. (1969) Structural studies on rabbit muscle glycerol-3-phosphate dehydrogenase and comparison of chemical and physical determinations of its molecular weights. J. Biol. Chem. 244, 1631-1644.

Fondy, T. P., Solomon, J. and Ross, C. R. (1971) Comparison of cytoplasmic glycerol-3-phosphate dehydrogenase from rat liver and muscle. Arch. Biochem. Biophys. 145, 601-611.

George, J. C. and Jyoti, D. C. (1955) Histological features of the breast and leg muscles of birds and bats and their physiological and evolutionary significance. J. Anim. Morph. Physiol. 11, 3135.

Gilbert, I. L. (1967) Lipid metabolism and function in insect. $A d v$. Insect Physiol. 4, 64-211. 
Gonzalez-Cerezo, H. and Dalziel, K. (1982) L- $\alpha$-glycerophosphate dehydrogenase from beef liver. Methods Enzymol. Vol. XLI, Part B. 259-264.

Green, D. E. (1936) $\alpha$-glycerophosphate dehydrogenase. Biochem. J. 30, 629-644.

Guppy, M. and Hochachka, P. W. (1978) Role of dehydrogenase competition in metabolic regulation, the case of lactase and $\alpha$ glycerophosphate dehydrogenase. J. Biol. Chem. 253, 84658469 .

Guppy, M. and Hochachka, P. W. (1978) Controlling the highest lactate dehydrogenase activity known in nature. Am. J. Physiol. 234, 2136-2140.

Gutierrez, M., de Burges, N. M. G., Burges, C. and Clanco, A. (1974) Correlation between muscular lactate dehydrogenase isozyme, patterns and flight habits of bats. Comp Biochem. Physiol. B.8, 379-388.

Holbrook, J., Liljas, A., Steindel, S. and Rossman, M. (1975) The Enzymes, Boyer, P. D., (ed.), Vol. II, Part A, Academic Press, New York, New York.

Klingenberg, M. and Bucher, T. H. (1960) Biological oxidations. Ann. Rev. Biochem. 29, 669-708.

Kito, M. and Pizer, L. I. (1969) Purification and regulatory properties of the biosynthetic L-glycerol-3-phosphate dehydrogenase from Escherichia coli. J. Biol. Chem. 244, 3316-3323.

Koekemoer, T. C., Litthauer, D. and Oelofson, H. J. (1995) Isolation and characterization of adipose tissue glycerol-3phosphate dehydrogenase. Int. J. Biochem. Cell. Biol. 27, 625632.

Kornbluth, R. A., Ostro, M. J., Rittman, L. S. and Fondy, T. P. (1974) Affinity chromatography of cytosolic NAD-linked glycerol-3-phosphate dehydrogenase from normal and neoplastic mammalian tissues. FEBS Lett. 39, 190-194.

Lee, Y. P. and Craine, J. E. (1971) L-glycerol 3-phosphate dehydrogenase: I. Effects of substrates on the catalytic properties of the hepatic nicotinamide adenine dinucleotidelinked enzyme from rabbit. J. Biol. Chem. 246, 7616-7622.

Lowry, D. H., Rosebrough, N. J., Fair, A. L. and Randell, R. J. (1951) Protein measurement with Folin phenol reagent. J. Biol. Chem. 193, 265-275.

Machado, M. F. and Contel, E. P. (1991) Glycerol-3-phosphate isoenzyme variation in adult meliponids (Hymeroptepron: Apidae). Biochem. Genet. 29, 93-600.

Marquart, R. R. and Brosemer, R. W. (1966) Insect extramitochondrial glycerophosphate dehydrogenase: Crystallization and physical properties of the enzyme from honey bee (Appis mellifera) Thoraces. Biochem. Biophys. Acta 128, 454-463.

McGinnins, J. F. and Vellis, J. (1974a) Purification and characterization of a rat brain glycerol phosphate dehydrogenase. Biochem. Biophys. Acta 364, 17-27.

McGinnis, J. F. and Vellis, J. A. (1974b) Novel affinity column for purification of glycerol phosphate dehydrogenase. Biochem.
Biophys. Res. Commun. 60, 186-195.

Okon, E. E., Umukoro, R. M. and Ajudua, A. (1978) Diurnal variations of the glycogen and fat stores in the liver and breast muscle of fruit bat, Eidolon helvum (Kerr). Physiol. Behav. 20, 121-123.

Ostro, M. J. and Fondy, T. P. (1977) Isolation and characterization of multiple molecular forms of cytosolic $\mathrm{NAD}^{+}$-linked glycerol3-phosphate dehydrogenase from normal and neoplastic rabbit tissues. J. Biol. Chem. 252, 5575-5583.

Ratner, P. L., Fisher, M., Burkart, D., Cook. J. R. and Kozak, L. P. (1981) The role of mRNA levels and cellular localization in controlling sn-glycerol-3-phosphate dehydrogenase expression in tissue of the mouse. J. Biol. Chem. 256, 3576-3579.

Ross, C. R., Curry, S., Schwatz, A. W. and Fondy, T. P. (1971) Multiple molecular forms of cytoplasmic glycerol-3-phosphate dehydrogenase in rat liver. Arch. Biochem. Biophys. 145, 591603.

Sacktor, B. (1965) Energetics and respiratory metabolism of muscular contraction (Rockstein, M., editor. The physiology of Insects,.), Vol. II, pp. 483-580, Academic Press, New York.

Sellinger, O. Z. and Miller, O. N. (1956) Anion inhibition of aglycerophosphate dehydrogenase. Nature (London) 183, 889890.

Thomas, S. P. (1975) Metabolism during flight in two species of bats, Phyllostomus hastatus and Pteropus gouldii. J. Exp. Biol. 63, 273-293.

Thomas, S. P. and Suther, R. A. (1972) The physiology and energetics of bat flight. J. Exp. Biol. 57, 317-335.

von Euler, H., Alder, E. and Gunther, G. (1937) The components of the dehydrase systems: XV. The dehydrogenation of $\alpha$ glycerophosphoric acid in the animal body. Z. Physiol. Chemie 249, 1-17.

Warburg, O. and Christian, W. (1942) Isolierung and Crystallization des garungsferments enolase. Biochem. Z. 310, 384-421.

Warkentin, D. L. and Fondy, T. P. (1973) Isolation and characterization of cytoplasmic L-glycerol-3-phosphate dehydrogenase from rabbit-renal adipose tissue and its comparison with skeletal muscle enzyme. Eur. J. Biochem. 36, 97-99.

Weber, K. and Osborn, M. (1975) Protein and sodium dodecyl sulphate. Molecular weight determination on polyacrylamide gels and related procedures: in The Proteins, Neurath, H. and Hill, R. L. (eds.), 3rd Ed., Vol. I., pp. 179-223, Academic Press, New York, New York.

White, H. B. and Kaplan, N. O. (1969) Purification and properties of two types of diphosphopyridine nucleotide linked glycerol-3phosphate dehydrogenases from chicken muscle and chicken liver. J. Biol. Chem. 244, 6031-6039.

Zolnierowicz, S., Swiercynski, J. and Zelewski, L. (1986) Isolation and properties of glycerol-3-phosphate oxidoreductase from human placenta. Eur. J. Biochem. 154, 161-166. 